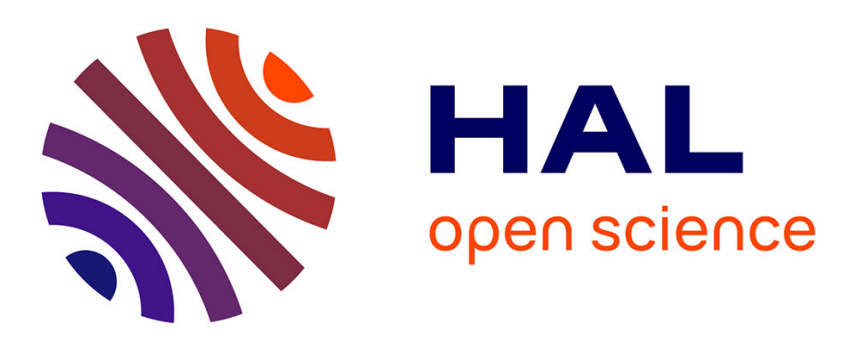

\title{
Factors Influencing Consumer's Behavioral Intention to Adopt IRCTC Connect Mobile Application
}

\author{
Ganesh P. Sahu, Monika Singh
}

\section{To cite this version:}

Ganesh P. Sahu, Monika Singh. Factors Influencing Consumer's Behavioral Intention to Adopt IRCTC Connect Mobile Application. 16th Conference on e-Business, e-Services and e-Society (I3E), Nov 2017, Delhi, India. pp.3-15, 10.1007/978-3-319-68557-1_1 . hal-01768527

\section{HAL Id: hal-01768527 https://hal.inria.fr/hal-01768527}

Submitted on 17 Apr 2018

HAL is a multi-disciplinary open access archive for the deposit and dissemination of scientific research documents, whether they are published or not. The documents may come from teaching and research institutions in France or abroad, or from public or private research centers.
L'archive ouverte pluridisciplinaire HAL, est destinée au dépôt et à la diffusion de documents scientifiques de niveau recherche, publiés ou non, émanant des établissements d'enseignement et de recherche français ou étrangers, des laboratoires publics ou privés.

\section{(c)(1)}

Distributed under a Creative Commons Attribution| 4.0 International License 


\title{
Factors Influencing Consumer's Behavioral Intention to Adopt IRCTC Connect Mobile Application
}

\author{
Ganesh P. Sahu ${ }^{1}$ and Monika Singh ${ }^{2}$ \\ ${ }^{1}$ Associate Professor, Motilal Nehru National Institute of Technology Allahabad \\ gsahu@mnnit.ac.in \\ ${ }^{2}$ Research Scholar, Motilal Nehru National Institute of Technology Allahabad \\ rms1502@mnnit.ac.in
}

\begin{abstract}
Indian Railway Catering and Tourism Corporation Ltd. (IRCTC) launched "IRCTC Connect" mobile application (app) for different mobile platforms for booking/cancellation tickets, but the app usage rate is very low in comparison to IRCTC website and Passenger Reservation System (PRS). This indicates a gap between implementation and adaption of IRCTC Connect. This paper explores the factors influencing the consumer's behavioral intention to use IRCTC Connect by adapting Unified Theory of Acceptance and Use of Technology 2 (UTAUT2) model. Regression analysis is used to analyze total 159 valid responses, collected through survey at MNNIT campus Allahabad, India. The findings of the study illustrate that only three factors Social Influence, Price Value and Habit of UTAUT2 model are significantly influencing the adoption of IRCTC Connect with adjusted R-Square value 0.699 . This study will facilitate IRCTC Connect developers to encompass better understanding on consumers' desires and intention and encourages researchers in this area for longitudinal observation in different backgrounds.
\end{abstract}

Keywords: IRCTC apps, IRCTC mobile application, IRCTC connect, UTAUT2, Determinants of consumer's behavior intention, $\mathrm{m}$-governance

\section{INTRODUCTION}

In today's lifestyle, all well educated, awarded and techno savoir-faire customers are highly cautious to adopt those applications and services which save their time and cost, and also applicable in the case of online Railway ticket booking [43-44]. Indian Railways have enabled the customers to book/ cancel ticket via website irctc.co.in and mobile app 'IRCTC Connect' instead of waiting in the ques at railways counters. Still approximately $54 \%$ of the Indian Railways tickets were reserved online and rest $46 \%$ were booked at the railway counters in 2014-15 financial year [34]. According to CRIS [11] report 54.4 million citizens booked tickets on railway counter in December 2015, whilst a total 183 billion tickets were booked through IRCTC website in

adfa, p. 1, 2011.

(C) Springer-Verlag Berlin Heidelberg 2011 
2014-15 and approximate 149 million tickets reserved till December 2015 [19].

Since, $\mathrm{m}$-Government ( $\mathrm{mGov}$ ) is an approach and its realization concern the employment of various wireless and mobile technologies, facilities, applications and procedures for benefits of all [3]. However, in developing countries like India, it is in initial stage of enlargement. The scope of expansion of online ticket booking is $80 \%$ in near future if Indian Railways and IRCTC will make its portal better [34]. It is apparent that there is a gap between government developed facilities and customers' intentions to accept the IRCTC Connect [22], [24, 25], due to which customers resists to use mobile apps in comparison to access the Railways counters or portals.

The study focused on investigation of the factors influencing customers' intentions to use IRCTC Connect. The findings will be helpful for policy makers in Indian Railways' to develop the strategies and upgrade mobile apps accordingly, so that, the outcome will meet the customers expectation. Subsequently, this study will be helpful for Indian government to make Digital India. Further, this study will enrich the existing literature. There are limited studies on mobile applications using this model. Therefore, it is an opportunity to explore the applicability of this theory in a small area of $\mathrm{m}$ governance i.e. IRCTC mobile app.

Following research methodology has been designed: A scrupulous Literature review followed by UTAUT2 model description and framing research model and hypotheses development. Afterward, Statistical Package for the Social Sciences (SPSS) is used for data analysis and interpretation. At the last discussion on results, and concluding remarks are laid down.

\subsection{Motivation \& Relevance of the research and its contribution}

As per the Telecom Regulatory Authority of India [48] records, till June 2015, there are 980.81 million peoples are wireless telephone (mobile phones) users with the $0.51 \%$ monthly development rate. The Urban mobile phones subscribers are 562.95 million ( $0.74 \%$ monthly growth rate) and Rural mobile phones subscribers are 417.85 million ( $0.22 \%$ monthly growth rate) making contribution of $57.40 \%$ and $42.60 \%$ respectively in mobile phone subscriber market. India is the second largest country after China which has crossed this milestone. Again India has more 213 million mobile internet users (above than $60 \%$ ) out of 352 million internet users according to Internet and Mobile Association of India [20], which shows that in India there is a wide scope for online marketing and $\mathrm{m}$ - governance services. Indian government has 
launched huge number of mobile applications in various segments (Health, Education, Electrical etc.), like mSwasthya, mTranslatorIndian, AADHAAR, MPMKVVCL, Kissan, MEESEWA and the list goes on, to offer $\mathrm{m}$-services more conveniently and to provide the citizen-centric platform empowering natives to hook up with the Indian Government and participate in building good governance [31], [33].

Table 1. Review of IRCTC Apps for multiple operating systems

\begin{tabular}{|l|l|l|l|l|}
\hline $\begin{array}{l}\text { IRCTC } \\
\text { Connect }\end{array}$ & $\begin{array}{l}\text { Android } \\
\text { App }\end{array}$ & $\begin{array}{l}\text { Apple's iOS } \\
\text { App }\end{array}$ & $\begin{array}{l}\text { Blackberry } \\
\text { App }\end{array}$ & $\begin{array}{l}\text { IRCTC Windows } \\
\text { App }\end{array}$ \\
\hline Launched & $\begin{array}{l}\text { October, } \\
2014\end{array}$ & $10^{\text {th }}$ Jan 2015 & August, 2014 & July, 2013 \\
\hline Bookings & $\begin{array}{l}15,90,563 \\
(2014-15)\end{array}$ & $\begin{array}{l}67,086 \\
(2014-15)\end{array}$ & $\begin{array}{l}11,585 \\
(2014-15)\end{array}$ & $\begin{array}{l}3,11,381 \\
(2014-15)\end{array}$ \\
\hline
\end{tabular}

Source: IRCTC Annual Report 2014-15 and irctc.co.in

Among all various mobile applications, winner of National award for EGovernance Best Citizen Centric application of year 2007-08, Indian Railway Catering and Tourism Corporation Ltd., Public Sector Enterprise under Ministry of Railway, launched "IRCTC Connect" official mobile app in October'2014 for android and Blackberry Smartphone users in August'2014, after a year of hosting "IRCTC Windows 8 App" for Windows phone users in July, 2013 [1920]. IRCTC app is also available on Apple's iOS platform by January'2015. Mobillion 2015 award winner 'IRCTC Connect' under category of 'Best Use of mobile app' has the motive behind offering ticket booking through multiple platforms is to attract maximum travelers and generate revenue [20].

\section{LITERATURE REVIEW}

Islam et al. [21] defined mobile apps as a set of application programmes that are used to perform a certain defined task for the mobile users. A number of user acceptance models identifying various factors are developed to measure the acceptance of information systems and technologies indicating the system's achievement or malfunctions [30]. In Bomhold [40] study students were considered for mobile apps usages calculation; Kang [23] using the Unified Theory of Acceptance and Use of Technology (UTAUT) \& Uses and Gratifications Theory (UGT) investigated the mobile apps usage intention.

Hew et al. [17] determined the factors that influence the mobile apps usage intention on the basis of UTAUT2 model. Oechslein et al. [36] and Raman and 
Dodds [14] found in their studies that UTAUT2 is the best fit model and all constructs taken for the study consistent with the model. Kapoor et al. [24] in their study analyzed and confirmed that 14 innovation attribute sets Image, Social Approval, Observability, Trialability, Visibility, Riskiness, Cost, Behavioral Intention, Voluntariness, Result Demonstrability, Compatibility, Communicability, Complexity, Relative Advantage from Diffusion of technology theory, Perceived Characteristics of Innovating theory [32], and metaanalysis [47] influences the adoption intention of IRCTC mobile ticketing.

\subsection{Model Selection for the Study:}

Diffusion of technology (DOI) [41] suggested five factors of innovation influencing the adaption attitude: compatibility, complexity, observability, relative advantage, and trialability [53]. Though, Crabbe et al. [10] suggested that DOI is more appropriate to examine diffusion across inhabitants, in comparison to individual adoption decisions. As per the Theory of Reasoned Action (TRA) [2] theory individual's behavior is straightforwardly prejudiced by its Behavioral Intention (BI) to apply the behavior, and the causal factors of BI are attitude and subjective standards. Ajzen's [2] Theory of Planned Behavior (TPB) model accumulated perceived behavioral control into TRA.

Technology acceptance model (TAM) model, proposed by Davis et al. [13], was modified from TRA model and recommended that individual's BI affects the real usage of system. In 2003, new model UTAUT was proposed by Venkatesh et al. [51] included eight different eminent IT acceptance and practice models. This model includes four key factors of $\mathrm{BI}$ and usage behavior (UB): Effort expectancy (EE), Facilitating conditions (FC), Performance expectancy (PE) and social influence (SI). Further, Venkatesh et al. [51] recommended that this model included the essences of those recognized models and is proficient to elucidate $70 \%$ of the variance in BI. In 2012, Venkatesh et al. [52] proposed extended theory UTAUT2 of UTAUT by including three more factors namely Hedonic Motivation (HM), Price Value (PV) and Habit (HA). Venkatesh et al. [52] claimed that UTAUT2 is the improved theory over UTAUT due to higher percentage value of variance in $\mathrm{BI}$ and technology uses. Therefore, we have adopted UTAUT2 model for this study. Also, there is limited study on mobile applications using this model. 


\section{CONCEPTS, HYPOTHESES AND RESEARCH MODEL}

\subsection{Direct Effects:}

PE: Rendering to Venkatesh et al. [51] Performance expectancy is the extent to which a person will achieve the expected goals in work performance by using the technology; $\mathrm{EE}$ is described as the extent to which a person will easily operate the system [54], [55]; SI is the degree to which a person is influenced by other individuals' believes that he should use that meticulous technology [32], [46], [52]. Pynoo et al. [38] highlighted that PE and EE are the combination of PU from TAM. Mobile devices especially smart phones are easy to operate [21], because of touch screen which provides more control [5], [7]. Also, if a system is easy to operate, learn and useful, intention to use that system increases [37]. Factors PE, EE and SI have direct positive impact on BI of accepting technology [8], [12, 13], [29] [45], [49-52]. Therefore, the hypotheses are:

H1: PE stands a direct positive impact on BI to use IRCTC Connect.

H2: EE stands a direct positive impact on BI to use IRCTC Connect.

H3: SI stands a direct positive impact on BI to use IRCTC Connect.

FC is described as the resources and technical support available to an individual to adapt the system [51]. In this study it is presumed that FC has a direct positive impact on $\mathrm{BI}$. Moreover, in different studies of mobile apps uses, mobile banking it is revealed that $\mathrm{FC}$ has direct positive impact on $\mathrm{BI}$ [9]. So the hypothesis is:

H4: FC stands a direct positive impact on BI to use IRCTC Connect.

\subsection{Added determinants and moderating effects:}

HM according to Brown and Venkatesh [6], is the associated pleasure with the usage of technology; PV according to Dodds et al. [15] is the consumers' intellective transaction among the apparent reimbursement of the applications and the expenses for using them; HA according to Venkatesh et al. [52] sculpted habit which affects directly or indirectly the use of the system and affected by $\mathrm{Bl} ; \mathrm{Bl}$ is the total efforts an individual is willing to made to achieve a goal and is the best predictor of real behavior. If a users feels pleasure and fun in using a technology, than they achieve enjoyment in using it [16], [27], [52]. According to Venkatesh et al. [52] the perceived benefits after expending the price (PV) on a technology affects the consumers inten- 
tion to use to technology. Moreover, a user's experience to use similar technologies affect the acceptance of new technologies is able to influence the adoption of a new technology [11]. There is a major impact of HA on mobile technologies and apps [7], [35]. Therefore the next hypotheses are:

H5: HM stands a positive impact on BI to use IRCTC Connect.

H6: PV stands a positive impact on BI to use IRCTC Connect.

H7: HA stands a positive impact on BI to use IRCTC Connect.

There are some moderating factors: age, gender and education. Male and female have diverse viewpoints in technology adaption decisions [52], [56]. According to Li et al. [30], the role of Education level moderator is ignored in previous studies and It is not included in UTAUT [1] and UTAUT2 [52] as a mediator. Therefore the effect of education level is not considered in the study. The study is based on youngsters at MNNIT Allahabad, India campus therefore the impact of age is insignificant. Consequently, the impact of only gender moderator is hypothesized:

$\mathrm{H} 8$ : The moderating factor gender stands influence on the constructs $\mathrm{FC}, \mathrm{HM}$, $\mathrm{PV}$ and $\mathrm{HA}$ of BI.

Research model developed for this study is shown in Figure 1. The relationships between the constructs are shown in the research. In the research model all the seven factors (independent variables) are constructs and Gender is role out as the moderating variables. Due to the cross-sectional study, experience is not taken into account and for model simplicity use behavior of consumers is abolished.

\section{RESEARCH DESIGN}

\subsection{Data Collection and Sample:}

The target population was the current users of mobile Internet technology especially users of IRCTC Connect. The survey was conducted in MNNIT Allahabad campus, since the young customers are more interested in new technology and innovation [29] also they are keen to adapt technology related to their entertainment, life style, comfort, inexpensive and less time taken [4], in the context of mobile applications. It is assumed that all the samples taken for the survey are/were users of IRCTC Connect.

To conduct the effective survey, a questionnaire is developed from the original questionnaire published in Venkatesh et al. [52] including all the con- 
structs PE, EE, SI, FC, HM, PV, HA and BI. All the items of the original established questionnaire were devised for researching customer's acceptance of technology.

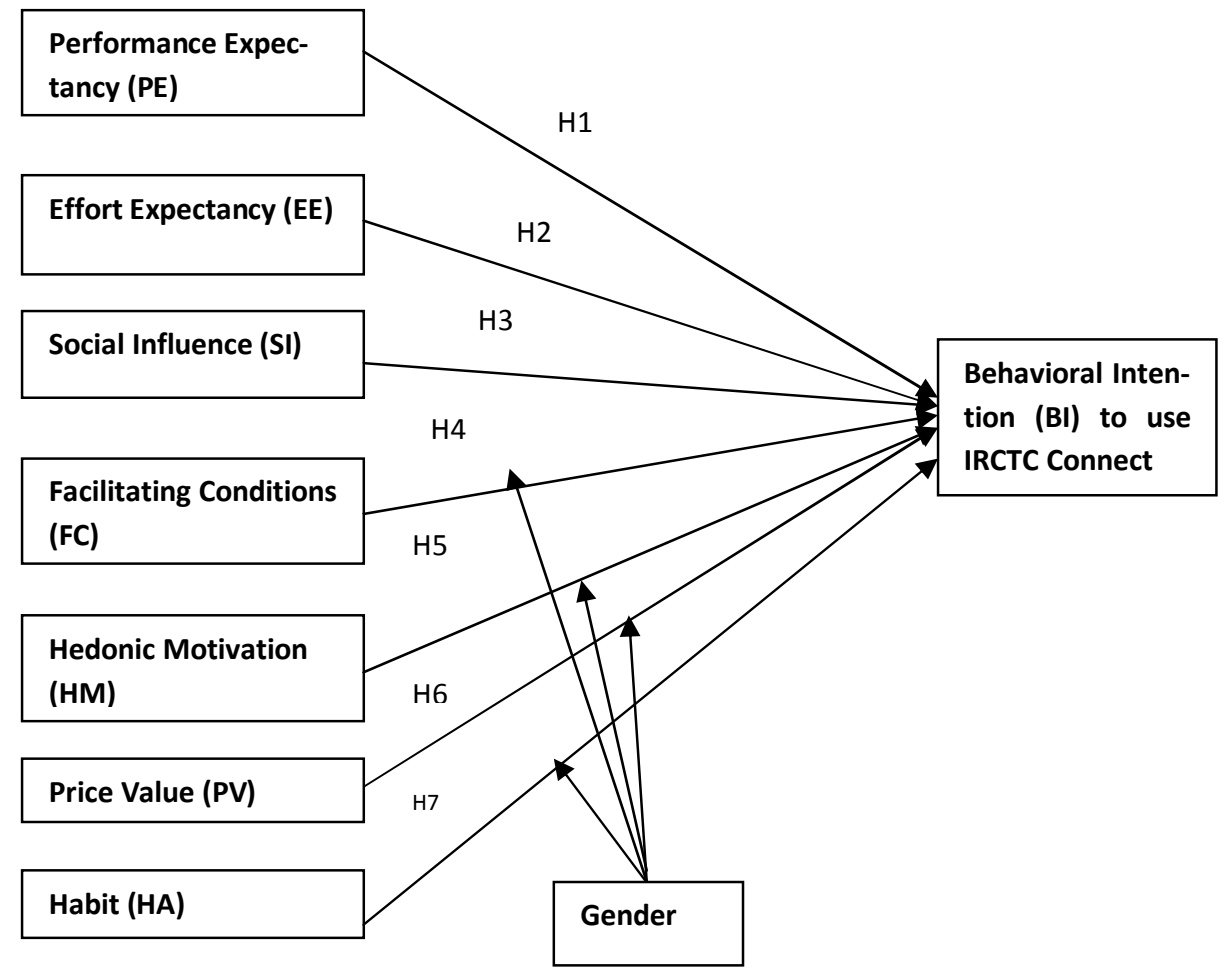

Fig. 1. Research Model for the study

\subsection{Measures:}

For this study 28 items to measure the constructs were taken. The measure scale used was comprised of 8 constructs namely: PE (4 items), EE (4 items), SI (3 items), FC (4 items), HM ( 3 items), PV ( 3 items), HA ( 4 items) and BI (4 items). In the questionnaire seven-point Likert scale was used in based on, 1 being strongly disagreed and 7 being strongly agreed. 200 questionnaires were randomly distributed in MNNIT Allahabad campus in all departments.

\section{DATA ANALYSIS}

\subsection{Demographic attribute of respondents:}

Out of 200 questionnaires, 183 filled questionnaires returned and 159 questionnaires found valid during analysis through SPSS. In 159 valid data maxi- 
mum respondents were female (54.1\%), age below 25 years $(82.4 \%)$ and educational background of graduation (66\%).

\subsection{STATISTICAL ANALYSIS}

\section{Reliability of the Constructs:}

Reliability analysis conducted on constructs through evaluating Cronbach's alpha evaluating. Table 2 shows the results of all constructs. For all constructs Cronbach's alpha values are above 0.7. Therefore, all the construct's Cronbach's alpha values indicate the internal consistency of the scale used in the study, confirming the reliability of the scale.

Table 2. Cronbach's alpha value for all items

\begin{tabular}{|c|l|c|c|l|c|}
\hline S.N. & Items & $\begin{array}{c}\text { Cronbach's } \\
\text { alpha Value }\end{array}$ & S.N. & Items & $\begin{array}{c}\text { Cronbach's al- } \\
\text { pha Value }\end{array}$ \\
\hline 1 & PE & 0.923 & 5 & HM & 0.892 \\
\hline 2 & EE & 0.815 & 6 & PV & 0.807 \\
\hline 3 & SI & 0.843 & 7 & HA & 0.856 \\
\hline 4 & FC & 0.792 & 8 & BI & 0.793 \\
\hline
\end{tabular}

The correlation analysis result is shown in the Table 3 . The results indicate that for all construct the correlation coefficients are above than 0.5 except for few constructs PV, HA and HM. Underneath the table it is mentioned that correlation is significant at the level 0.01 and in the results it is found that significance values for all correlation coefficients are 0.00 i.e. less than .01 Therefore there are statistically significant relationship for the behavior intention of the customer to use IRCTC Connect.

\section{Regression Analysis and Result}

a. Regression diagnostics.

The histogram drawn to test the normality, the distribution of residuals was approximately symmetric and unimodal fulfilling the normality test postulation and scatter-plot plot indicated the linearity of the distribution. The nonexistence of multicollinearity and heteroscedasticity was examined through Bartlett test of sphericity, since the Barlett's signicant value is less than .05 refer Table 4. 
Table 3. Correlation table for all the dependent and independent variables

\begin{tabular}{|l|l|l|l|l|l|l|l|l|l|l|}
\hline $\begin{array}{l}\text { Con- } \\
\text { structs }\end{array}$ & Mean & $\begin{array}{l}\text { Standard } \\
\text { Deviation }\end{array}$ & PE & EE & SI & FC & HM & PV & HA & BI \\
\hline PE & 5.142 & 1.178 & 1 & & & & & & & \\
\hline EE & 5.441 & 0.848 & $.798^{* *}$ & 1 & & & & & & \\
\hline SI & 4.991 & 1.145 & $.625^{* *}$ & $.538^{* *}$ & 1 & & & & & \\
\hline FC & 5.264 & 0.953 & $.721^{* *}$ & $.740^{* *}$ & $.639^{* *}$ & 1 & & & & \\
\hline HM & 4.807 & 1.156 & $.450^{* *}$ & $.393^{* *}$ & $.530^{* *}$ & $.447^{* *}$ & 1 & & & \\
\hline PV & 5.128 & 1.063 & $.499^{* *}$ & $.504^{* *}$ & $.438^{* *}$ & $.498^{* *}$ & $.405^{* *}$ & 1 & & \\
\hline HA & 4.849 & 1.186 & $.499^{* *}$ & $.441^{* *}$ & $.641^{* *}$ & $.536^{* *}$ & $.576^{* *}$ & $.524^{* *}$ & 1 & \\
\hline BI & 5.200 & 1.073 & $.576^{* *}$ & $.535^{* *}$ & $.636^{* *}$ & $.571^{* *}$ & $.530^{* *}$ & $.650^{* *}$ & $.778^{* *}$ & 1 \\
\hline
\end{tabular}

**Correlation is significant at the 0.01 level (2-tailed).

Table 4. Bartlett's Test results

\begin{tabular}{|c|c|c|}
\hline \multicolumn{3}{|l|}{ Bartlett's Test of Sphericity } \\
\hline & Approx. Chi-Square & 3270.642 \\
\hline & Df & 378 \\
\hline & Sig. & .000 \\
\hline
\end{tabular}

The Durbin-Watson value 2.097 found which is nearer to 2 , indicating the freedom of error term. The nonexistence of outlier and influential observations examined through the normal $p-p$ plot analysis presenting a straight line against the dependent observation.

To determine the relationship between predictors linear regression conducted. The results are presented in Figure 2 and Table 5. The regression results shows that Performance expectancy has no effect on Behavioral Intention to use IRCTC apps as the p-value of 0.407 is greater than 0.05 . Hence, $\mathrm{H} 1$ is rejected. Again, the results show that "Effort expectancy" also has no effect on Behavioral Intention to use IRCTC Connect as its p-value $=0.465$ (>0.05). Thus, $\mathrm{H} 2$ is also rejected. Likewise Facilities Condition and Hedonic motivation has no impact on Behavioral Intention to use IRCTC Connect since the $p$ values are 0.944 and 0.667 respectively which are greater that $p=.05$. Therefore, hypotheses $\mathrm{H} 4$ and $\mathrm{H} 5$ are also rejected. Whilst there is positive impact of Social Influence on Behavioral Intention to use IRCTC Connect as $p=.048(<0.05)$ which leads to acceptance of H3. Similarly, there are also positive impacts of PV and HA on Behavioral Intention to use IRCTC Connect as 
the $p$-values are 0.00 for both the constructs. Therefore, again, the results lead to the acceptance of hypotheses $\mathrm{H} 6$ and $\mathrm{H} 7$.

In Table 5, the value of $\mathrm{R} 2=0.71$ indicates that the predictors account for $71 \%$ variation in the customer's Behavioral Intention to use IRCTC Connect. And rest of $29 \%$ variation explained by some other predictors. Since the value of F-ratio 53.377 is significant (as $p$-value $=0.00$ is less than 0.05 ), therefore, there is less than a $0.1 \%$ chances that an F-ratio this big would occur if all the null hypotheses were true.

Table 5. Regression Model Summary

\begin{tabular}{l}
\begin{tabular}{|l|l|l|l|l|}
\hline \multicolumn{5}{|c|}{ Model Summary $^{\text {b }}$} \\
\hline Model & R & R Square & Adjusted R Square & $\begin{array}{l}\text { Std. Error of } \\
\text { the Estimate }\end{array}$ \\
\hline 1 & $.844^{\text {a }}$ & .712 & .699 & .58861 \\
\hline $\begin{array}{l}\text { a: Predictors: (Constant), HA, EE, HM, PV, SI, FC, PE } \\
\text { b: Dependent Variable: BI }\end{array}$
\end{tabular} \\
\hline
\end{tabular}

Comparative significance based on regression output:.

The unstandardized $\beta$-coefficient for the predictors ranges from -0.006 to .440 . It is necessary to examine the $p$-values of predictors before moving to standardized $\beta$ coefficients. The results from the coefficient Table 5 presents that Habit, Price value and Social Influence have the significant standardized $\beta$-coefficients (as $p$-values are less than 0.05 at $5 \%$ significance level). Hence the "Habit" is the mainly essential factor influencing the customer behavioral intention to use IRCTC Connect (with standardized $\beta$ of 0.486 ) followed by Price Value (with standardized $\beta$ of 0.271 ) and with "Social Influence" having the least impact (with standardized $\beta$ of 0.123). Table 6 presents the final results of the acceptance or rejection of hypotheses based on regression results.

Table 6. Hypotheses outcome

\begin{tabular}{|l|c|l|}
\hline Hypotheses & $\begin{array}{c}\beta- \\
\text { coefficients }\end{array}$ & Conclusion \\
\hline $\begin{array}{l}\text { H1: PE stands a direct positive impact on BI } \\
\text { to use IRCTC Connect. }\end{array}$ & .067 & Rejected \\
\hline
\end{tabular}




\begin{tabular}{|l|l|l|}
\hline $\begin{array}{l}\text { H2: EE stands a direct positive impact on BI } \\
\text { to use IRCTC Connect. }\end{array}$ & .059 & Rejected \\
\hline $\begin{array}{l}\text { H3: SI stands a direct positive impact on BI to } \\
\text { use IRCTC Connect. }\end{array}$ & .123 & Accepted \\
\hline $\begin{array}{l}\text { H4: FC stands a direct positive impact on BI } \\
\text { to use IRCTC Connect. }\end{array}$ & -.005 & Rejected \\
\hline $\begin{array}{l}\text { H5: HM stands a positive impact on BI to use } \\
\text { IRCTC Connect. }\end{array}$ & .024 & Rejected \\
\hline $\begin{array}{l}\text { H6: } \text { PV stands a positive impact on BI to use } \\
\text { IRCTC Connect. }\end{array}$ & .271 & Accepted \\
\hline $\begin{array}{l}\text { H7: HA stands a positive impact on BI to use } \\
\text { IRCTC Connect. }\end{array}$ & .486 & Accepted \\
\hline
\end{tabular}

Regression analysis is used to see the effect of moderator gender on constructs FC, HM, PV and HA. The results found were insignificant coefficients of moderators for four constructs Facilitating Condition, Hedonic Motivation, Price Value and Habit as the $p$ values found was $p=0.200, .05,0402$ and 0.620 (always greater than $\mathrm{p}=0.05$ ) respectively. Therefore, it is concluded that the impact of gender is insignificant leading to rejection of hypothesis $8(\mathrm{H} 8)$. Thus the final research model is presented in figure 2 .

\subsection{DISCUSSION}

On the basis of results of the regression analysis three constructs 'Social Influence', 'Price Value' and 'Habit' were established significant and direct positive impact on Behavioral Intention to use IRCTC Connect and rest of other four factors did not have any significant positive relationship with Behavioral Intention to use IRCTC Connect [Fig. 2.]. Also it was found that gender is not moderating the relationship between predictors and outcome. 


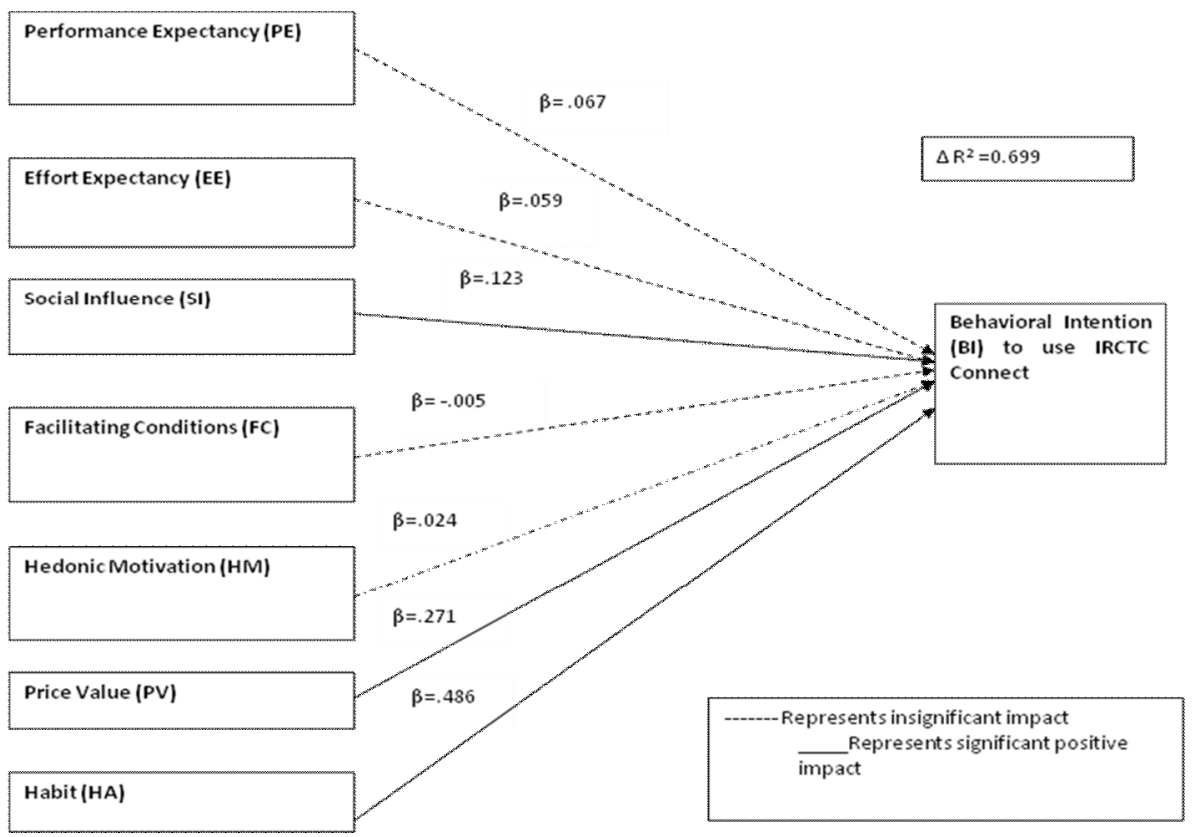

Fig. 2. Final Research Model of the study

$P E, E E, F C$ and $H M$ insignificantly influence Behavioral Intention to use IRCTC Connect which is contradiction to the previous studies done by Lewis et al $[25,26],[28],[35],[52]$. The reason for rejection of hypothesis H1, H2, H4 and $\mathrm{H} 5$ may be availability of other options. Since MNNIT Allahabad campus is fully Wi-Fi enabled and near to Prayag Railway Station Allahabad, enables the students to easily access the irctc.co.in website on their mobile or laptop. The IRCTC website is easy to use not only for booking or cancelling tickets but also for other advanced features in comparison to IRCTC Connect. Also, many students prefer to book ticket via PRS because it is on walking distance and validity of waiting tickets booked on counter. Moreover, Tatkal reservation is still not available on IRCTC connect, directing students to book via IRCTC website or PRS. Therefore, the performance of IRCTC Connect, efforts made to use this app as well as resources availability for using this app do not influence student's intention. Additionally, in this competitive epoch when all commercial apps are offering various discounts, IRCTC Connect does not provide any reward points or discounts on booking tickets, creating the lack of interest and fun to use this. IRCTC does not offer any feature which attracts the customers to use this app presents the possible reason behind the insignificant impact of hedonic motivation on consumer's behavioral intention. 
$\mathrm{SI}, \mathrm{PV}$ and $\mathrm{HA}$ are the factors which effects the Behavioral Intention to use IRCTC Connect which is consistent with the previous studies. The reason may be youngsters follow their elders and influenced by their peers to use any services and applications. Youngsters use those applications which do not require extra amount to be paid, indicating the direct positive impact of PV on $\mathrm{BI}$.

\section{CONCLUDING REMARKS}

This paper is an attempt to investigate the factors which leads to IRCTC Connect usage. The paper initially discuss the background and motivation of the study presenting how many number of citizens are using IRCTC apps and what factors influence consumer to use IRCTC Connect mobile app. Using UTAUT2 model, new model is proposed with a detailed account of factors of consumer intention to use IRCTC Connect. The results presented that Social Influence, Price Value and Habit are the three factors influence the behavioral intention of people to use IRCTC apps with coefficient $\beta$ values $0.123,0.271$ and 0.486 respectively out of seven factors of UTAUT2 model rest four factors Performance expectancy, Effort expectancy, Facilitating Condition and Hedonic Motivation do not influence the Behavioral intention to use IRCTC Connect.

This study is useful for IRCTC managers to make strategies and develop and upgrade their apps accordingly. Further this study will be helpful for the researchers to replicate further concern in this area (Mygov APP) and will enrich the literature review. The limitation of the study was the samples (limited to only MNNIT Allahabad) and limited availability of resources for literature review.

\section{REFERENCES}

1. Abu-Shanab, E. A. :Education level as a technology adoption moderator. In Computer Research and Development (ICCRD), 2011 3rd International Conference IEEE. Vol. 1, pp. 324328, (2011)

2. Ajzen, I., \& Fishbein, M. :Understanding attitudes and predicting social behavior. Englewood Cliffs, NJ: Prentice-Hall, (1980).

3. Antovski, L., \& Gusev, M. :M-government framework. Proceedings EURO mGov, 10-12, (2005).

4. Bigne, E., Ruiz, C., \& Sanz, S. : The impact of internet user shopping patterns and demographics on consumer mobile buying behaviour. Journal of Electronic Commerce Research, vol. 6(3), p.193, (2005). 
5. Brasel, S. A., \& Gips, J. :Interface Psychology: Touchscreens Change Attribute Importance, Decision Criteria, and Behavior in Online Choice. Cyberpsychology, Behavior, and Social Networking, vol. 18(9), pp. 534-538, (2015).

6. Brown, S. A., \& Venkatesh, V. :Model of adoption of technology in households: A baseline model test and extension incorporating household life cycle. MIS quarterly, pp.399-426, (2005).

7. Chang, C. C., Yan, C. F., \& Tseng, J. S. Perceived convenience in an extended technology acceptance model: Mobile technology and English learning for college students. Australasian Journal of Educational Technology, vol. 28(5),pp. 809-826 (2012).

8. Chong, A. Y. L. :Predicting m-commerce adoption determinants: A neural network approach. Expert Systems with Applications, vol. 40(2), pp. 523-530, (2013).

9. Chuang, Y. F. :Pull-and-suck effects in Taiwan mobile phone subscribers switching intentions. Telecommunications Policy, vol. 35(2), pp. 128-140, (2011).

10. Crabbe, M., Standing, C., Standing, S., \& Karjaluoto, H. :An adoption model for mobile banking in Ghana. International Journal of Mobile Communications, vol. 7(5), pp. 515-543 (2009).

11. CRIS. Progress of projects in CRIS. STATUS OF PROJECTS AT A GLANCE . New Delhi, India (January, 2016). Retrieved on January 29, 2016, from http://cris.org.in/CRIS/PDF/Progress_of_IT_projects.pdf

12. Davis, F. D. :Perceived usefulness, perceived ease of use, and user acceptance of information technology. MIS quarterly, pp. 319-340, (1989).

13. Davis, F. D., Bagozzi, R. P., \& Warshaw, P. R. :User acceptance of computer technology: a comparison of two theoretical models. Management science, vol. 35(8), pp. 982-1003, (1989).

14. Dodds, W. B., Monroe, K. B., \& Grewal, D. :Effects of price, brand, and store information on buyers' product evaluations. Journal of marketing research, pp. 307-319, (1991).

15. Dodds, W. K., \& PRISCU, J. C. :An inexpensive device for sampling large volumes of lake water from discrete depths. Freshwater Biology, vol. 20(1), pp. 113-115 (1988).

16. Gu, J. C., Lee, S. C., \& Suh, Y. H. . Determinants of behavioral intention to mobile banking. Expert Systems with Applications, vol. 36(9), pp. 11605-11616, (2009).

17. Hew, J. J., Lee, V. H., Ooi, K. B., \& Wei, J. What catalyses mobile apps usage intention: an empirical analysis. Industrial Management \& Data Systems, vol. 115(7), pp 1269-1291, (2015).

18. IAMAI : Internet and Mobile Association of India 11th Annual Report 2014-15. New Delhi: Dr. Subho Ray on behalf of IAMAI, (September, 2015.

19. IRCTC, :IRCTC 16 Annual Report 2014-2015. 22. New Delhi, New Delhi, India: Vijaylakshmi Printing Works Pvt. Ltd (July 9, 2015).. Retrieved on January 23, 2016

20. irctc.com.: IRCTC: A progress profile (2002). Retrieved January Sunday, 2016, from irctc.com: http://irctc.com/Company_Profile.html

21. Islam, R., Islam, R., \& Mazumder, T. : Mobile application and its global impact. International Journal of Engineering \& Technology IJET-IJENS, (2002).vol 10(6), pp 72-78, (2010).

22. Kailasam, R. : m-Governance... Leveraging Mobile Technology to extend the reach of eGovernance. In Proceedings of the TRAI conference on Mobile Applications for Inclusive Growth and Sustainable Development (2010). 
23. Kang, S.:Factors influencing intention of mobile application use. International Journal of Mobile Communications, vol. 12(4), pp.360-379, (2014).

24. Kapoor, K. K., Dwivedi, Y. K., \& Williams, M. D., :IRCTC mobile ticketing adoption in an Indian context. International Journal of Indian Culture and Business Management, vol. 11(2), pp. 155-183, (2015a).

25. Kapoor, K. K., Dwivedi, Y. K., \& Williams, M. D. :Empirical Examination of the Role of Three Sets of Innovation Attributes for Determining Adoption of IRCTC Mobile Ticketing Service. Information Systems Management, vol. 32(2), pp. 153-173, (2015b).

26. Lewis, K.N., Palmer, A .and Moll, A. :Predicting young consumer's take up of mobile banking services", International Journal of Bank Marketing, Vol. 28 No. 5, pp. 410-432, (2010).

27. Leong, L. Y., Ooi, K. B., Chong, A. Y. L., \& Lin, B. :Modeling the stimulators of the behavioral intention to use mobile entertainment: Does gender really matter?. Computers in $\mathrm{Hu}$ man Behavior, vol 29(5), pp. 2109-2121, (2013).

28. Li, H., Kuo, C., \& Rusell, M. G.: The impact of perceived channel utilities, shopping orientations, and demographics on the consumer's online buying behavior. Journal of Computer-Mediated Communication,vol. 5(2), (1999).

29. Luo, X., Li, H., Zhang, J., \& Shim, J. P.:Examining multi-dimensional trust and multi-faceted risk in initial acceptance of emerging technologies: An empirical study of mobile banking services. Decision support systems, vol. 49(2), pp.222-234, (2010).

30. Melone, N. P. : A theoretical assessment of the user-satisfaction construct in information systems research. Management science, vol. 36(1), pp.76-91, (1990).

31. Mobile Seva. Mobile Seva Appstore (January, 2016). Retrieved January 25, 2016, from Mobile Seva: https://apps.mgov.gov.in/liveapp.do

32. Moore, G. C., \& Benbasat, I. :Development of an instrument to measure the perceptions of adopting an information technology innovation. Information systems research,vol. 2(3), pp. 192-222. (1991).

33. MyGov (2016). MyGov.in. Retrieved January 25, 2016, from MyGov.in: https://mygov.in/overview/

34. mytrainstatus.com. IRCTC Makes 35 seconds to Wait to Book Tickets(January, 2016). Retrieved January 28, 2016, from Indian Railways, mytrainstatus: https://mytrainstatus.com/blog/irctc-makes-35-seconds-to-waitto-book-tickets/

35. Nikou, S., \& Bouwman, H. :Ubiquitous use of mobile social network services. Telematics and Informatics, vol 31(3), pp. 422-433 (2014).

36. Oechslein, O., Fleischmann, M., \& Hess, T. :An Application of UTAUT2 on Social Recommender Systems: Incorporating Social Information for Performance Expectancy. In System Sciences (HICSS), 2014 47th Hawaii International Conference IEEE. pp. 32973306, (2014)

37. Pikkarainen, T., Pikkarainen, K., Karjaluoto, H., \& Pahnila, S.: Consumer acceptance of online banking: an extension of the technology acceptance model. Internet research,vol 14(3), pp. 224-235, (2004).

38. Pynoo, B., Devolder, P., Tondeur, J., Van Braak, J., Duyck, W., \& Duyck, P. :Predicting secondary school teachers' acceptance and use of a digital learning environment: A crosssectional study. Computers in Human Behavior, vol. 27(1), pp. 568-575, (2011). 
39. Raman, A., \& Don, Y. : Preservice teachers' acceptance of learning management software: An Application of the UTAUT2 Model. International Education Studies, vol. 6(7), p.157 (2013).

40. Reese Bomhold, C.:Educational use of smart phone technology: A survey of mobile phone application use by undergraduate university students. Program, vol.47(4), pp. 424-436, . (2013).

41. Rogers, E. M. Diffusion of Innovations: modifications of a model for telecommunications. Die Diffusion von Innovationen in der Telekommunikation, vol 17, pp. 25-38, (1995).

42. Rogers, E. M. :Diffusion of innovations (5th ed.). New York, NY: The Free Press (2003).

43. Sahney, S., Ghosh, K., \& Shrivastava, A. :Buyer's motivation" for online buying: an empirical case of railway e-ticketing in Indian context .Journal of Asia Business Studies, vol. 8(1), pp. 43-64 (2013a)

44. Sahney, S., Ghosh, K., \& Shrivastava, A : Conceptualizing consumer "trust" in online buying behaviour: an empirical inquiry and model development in Indian context. Journal of Asia Business Studies, vol. 7(3), pp. 278-298(2013b). http://doi.org/http://dx.doi.org/10.1108/JABS-Jul-2011-0038

45. Taylor, S., \& Todd, P. A. :Understanding information technology usage: A test of competing models. Information systems research,vol 6(2), pp. 144-176, (1995).

46. Thompson, R. L., Higgins, C. A., \& Howell, J. M. Personal computing: Toward a conceptual model of utilization. MIS quarterly, pp. 125-143, (1991).

47. Tornatzky, L. G., \& Klein, K. J. :Innovation characteristics and innovation adoptionimplementation: A meta-analysis of findings. Engineering Management, IEEE Transactions, vol. (1), pp. 28-45 (1982).

48. TRAI :Telecom regulatory authority of India. Delhi: TRAI(2015).

49. Venkatesh, V., \& Davis, F. D. :A theoretical extension of the technology acceptance model: Four longitudinal field studies. Management science,vol 46(2), pp.186-204, (2000).

50. Venkatesh, V., \& Morris, M. G.: Why don't men ever stop to ask for directions? Gender, social influence, and their role in technology acceptance and usage behavior. MIS quarterly, pp 115-139(2000).

51. Venkatesh, V., Morris, M. G., Davis, G. B., \& Davis, F. D. :User acceptance of information technology: Toward a unified view. MIS quarterly, pp. 425-478, (2003).

52. Venkatesh, V., Thong, J. Y., \& Xu, X. Consumer acceptance and use of information technology: extending the unified theory of acceptance and use of technology. MIS quarterly, vol 36(1),pp. 157-178 (2003).

53. Yahya, M., Nadzar, F., Masrek, N., \& Rahman, B. A. :Determinants of UTAUT in measuring user acceptance of e-Syariah portal in syariah courts in Malaysia. In The 2nd International Research Symposium in Service Management Yogyakarta, Indonesia (2011, July).

54. Yang, K. C. Exploring factors affecting the adoption of mobile commerce in Singapore. Telematics and informatics, vol.22(3), pp.257-277, (2005).

55. Zhou, T., Lu, Y., \& Wang, B. :Integrating TTF and UTAUT to explain mobile banking user adoption. Computers in human behavior, vol. 26(4), pp. 760-767, (2010). 